Available online at: https://www.researchsynergy.org/jsetp/

Journal of Social Entrepreneurship Theory and Practice (JSETP)

ISSN (to be assigned soon)

Volume 1 Number 1 (2021): 68-83

\title{
How Far the Digital Marketing Innovation done by Natural Raw Material MSMEs during the Pandemic? Case of Magelang Region, Central Java Region, Indonesia
}

\author{
Hironimus Leong1, Berta Bekti Retnawati2, B. Irmawati² \\ ${ }^{1}$ Computer Science Department, Soegijapranata Catholic University, Indonesia \\ ${ }^{2}$ Economics and Business Department, Soegijapranata Catholic University, Indonesia
}

\begin{abstract}
There are various steps taken by Natural Raw Materials MSMEs in Magelang Region in facing the economic downturn during the pandemic for their business continuity. The effort to adapt to the difficulties during the pandemic period is by utilizing information technology to encourage the economy to continue growing and developing. The use of social media and e-commerce is an example of marketing adaptation from a traditional form to a more modern model. Participation in virtual exhibitions is also another example of how MSMEs adopt digital transformation. The study aims to determine how far the natural raw material MSMEs actors can utilize the digital marketing during the pandemic and prepare for the adaptation in the new normal period. This study uses a qualitative descriptive approach involving 30 MSMEs. The result shows that MSMEs who are transitioning away from traditional marketing techniques and attempting to be innovative in response to environmental changes have a chance to sustain themselves. Marketing via e-commerce, social media, and virtual product introduction can help to increase markets and enhance the economy. Those that are not prepared for the adaption process, on the other hand, will choose to operate other businesses or even close them.
\end{abstract}

Keywords: MSMEs; Digital Marketing; Information Technology; Pandemic; Natural Materials

This is an open access article under the CC-BY-NC license.

\section{INTRODUCTION}

The Corona pandemic in this country has been going on for almost three-quarters of the year. The impact affects the life order in society on all fronts, including in the economic sector. The economic sector has experienced a lot of contraction due to the recommendation of health protocols such as physical distancing, crowd's avoidance, even the recommendation to stay at home have changed all the patterns and structures of society's lives.

The MSMEs sector has got the worst impact because, during the pandemic, almost all MSMEs choose to stop their production or at least switch their business to other fields. The main factor that makes the business worse is the loss of the market. MSMEs face the loss of the market that supplies raw materials as well as the loss of the market for product sales. The impact is the decrease in production and also society's purchasing power.

Changes in this kind of situation require new adaptation patterns so that MSMEs can survive or even regain the economic market in the country. In various sectors of life, the most significant change is the massive use of digital technology. The world is experiencing an acceleration towards

Corresponding author

Hironimus Leong, marlon.leong@unika.ac.id

DOI: (to be assigned soon)

Research Synergy Foundation 
the industrial revolution 4.0. In the economic sector, a new strategy has also emerged by carrying out digital transformation. Currently, Indonesia is experiencing the flow of a digital economy, marked by the increasing number of businesspeople adopting online technology for working, studying and shopping transactions.

The industrial revolution is a new era or order marked by fundamental changes in industrial sectors that affect values in society. Automation and data are the keywords in the industrial revolution that generate future technologies such as Big Data, IoT (Internet of Things), cloud computing (Cloud Computing), and cognitive computing capabilities (Artificial Intelligence - AI). The role of humans is reduced and even no longer dominant because all work and traditional methods are completed by using computers so that many things are substituted and even disappear, and their role is replaced by intelligent machines. Therefore, the industrial revolution is also called the era of disruption. Smart machines are easily integrated into digital devices that can help MSME businesses reach wider customers, expand markets, and also increase product creativity. However, there are 3 things that become challenges to MSMEs, such as limited information, access barriers and digital services that have not been integrated yet. These challenges can only be answered with the availability of adequate infrastructure, the support for digital platforms as an ecosystem for MSME players, and of course, increasing digital literacy for MSME players.

The concept of small and medium enterprises (SMEs) or micro, small and medium enterprises (MSMEs) refers to the rule of law Number 20-year 2008 concerning Micro, Small and Medium Enterprises - MSMEs or micro-enterprises. MSMEs are defined as sectors that have annual sales of 300 million rupiahs at the most. Generally, business is carried out at the household level, which is engaged in the handicraft, food and beverage, clothing and household appliances sectors. That means legally and formally, its role has been listed and regulated in the form of legislation. MSMEs play an important role in the economic circulation of development because they are able to open job vacancies, increase people's income and also help the government in the process of poverty alleviation.

Thus, the severe impact on MSMEs during the pandemic will directly impact the national economy. The government tries to provide social protection for MSMEs through productive assistance such as budget and equipment contributions, training assistance, tax incentives, interest subsidies, and so on during the pandemic. Assistance for MSMEs from the central government is realized up to the regional level. Trainings for MSMEs to improve digital marketing capabilities aim to expand the marketing reach of handicraft products.

There is not much statistical information related to the number of MSMEs engaged in naturalbased raw materials in the Magelang Region - Central Java. The research team has noted several types of handicrafts made of natural raw materials such as handicrafts from wood, bamboo, shells and horns. Generally, MSMEs that are engaged in natural raw materials produce products that are very close to tourism. This is inseparable from Magelang region, which is included in the trade and tourism center.

During the pandemic, tourism is one of the sectors that gets the worst impact which indirectly becomes a domino effect that also affects MSMEs as the economic activator of the creative economy. There are several sub-sectors that support the creative economy, namely advertising, architecture, 
Journal of Social Entrepreneurship Theory and Practice (JSETP), Vol. 1 (1), 68-83

How Far the Digital Marketing Innovation done by Natural Raw Material MSMEs during the Pandemic?

Case of Magelang Region, Central Java Region, Indonesia

Hironimus Leong, Berta Bekti Retnawati, B. Irmawati

the art market, design, fashion, music, interactive games, broadcasting, video - film - photography, including the craft sector from natural raw materials. MSMEs that use natural raw materials to be processed into production rely on the expertise, talent and creativity. The results of the product that have high artistic values need to be distributed to the market. The biggest challenge is trying to adapt to the people's behavior change patterns, one of which is the transformation of digital marketing, which is changing the traditional conventional ways of marketing towards the era of digital marketing.

It is important to review the innovation of MSMEs in taking advantage of digital technology to expand the product marketing reach, in running the economic life to be better, and in giving the major results to the country's economy directly in the pandemic condition and the early phase of the new habits. Therefore, the main purpose of this research is to see how far the digital marketing innovation done by MSMEs players in facing this crisis situation during this pandemic, and also in surviving and adapting to the changes in society in the era of new habits.

\section{LITERATURE REVIEW}

The concept of small and medium enterprises (SMEs) or micro, small and medium enterprises (MSMEs) refers to the rules of Law Number 20 of 2008 about Micro, Small, and Medium Enterprises. MSMEs or micro-enterprises are individually owned businesses or individual business entities that are productive, and that meet the criteria written by law (Soetjipto, 2020). Based on data released by the cooperative department, the number of MSMEs in Indonesia in 2017 has been approximately 63 million (Data on UMKM, 2020). One of the factors that greatly affect the development of MSMEs in Indonesia is the use of information and communication technology, particularly social media for digital marketing and also e-commerce platforms for online sales transactions.

Digital is defined as 'a participatory layer of all media that allows users to self-select their own experiences, and affords marketers the ability to bridge media, gain feedback, iterate their message, and collect relationships" (Caddell, 2020). In other words, digital is a new way of exploring content (for users) and connecting with customers (for marketers). Whereas marketing is defined as "is that function of the organization that can keep in constant touch with the organization consumers, read their needs, develop products that meet these needs, and build a programme of communications to express the organization's purposes" (Kotler \& Levy, 1969). From the definition, there is no basic difference between conventional traditional marketing and digital marketing because both of them have the same purpose, which is maintaining the buyers and stimulating the selling. The difference is in the use of the media; digital communication equipment enables to link and builds long term relationships with customers, where the power of the internet is needed. There are at least media elements that can be used for digital marketing, for example, website, search engine optimization (SEO), pay per click search advertising (PPC), Affiliate/performance marketing and strategic partnerships, Online public relations, Social media, E-mail marketing, Mobile Marketing, Customer relationship management, Content marketing, and Display Media (Ryan, 2014).

This digital marketing enables MSMEs players to move to a more horizontal, inclusive and social from the point of view of the business. So, the market becomes more inclusive. Digital marketing solves the off geographical and demographic problems. People can get connected, can 
communicate, and can innovate and collaborate. The buyers become more horizontal-oriented where marketing needs communication of the brand and counts on the relation factors, families, fans, and followers (Kotler, Kartajaya, \& Setiawan, 2017). Finally, the customers become more social than before. The customers pay more attention to their social circle in making a decision. They will try to find suggestions and testimonies both online and offline.

As part of the creative industry, MSMEs, especially natural handicrafts, have high artistic and creative power. MSMEs that produce products from natural raw materials have great potential to be developed (Retnawati \& Irmawati, 2018). The sources of natural raw materials are abundant, and they can be developed into products that are ready to be marketed. It takes creativity, innovation and artistic values in producing products made from natural materials. Products can be marketed online in line with market developments during the pandemic period. People start to transform from traditional shopping patterns to online consumption patterns (Silvatika, 2020).

\section{RESEARCH METHOD}

This study describes the conditions of MSMEs with natural raw materials in various regions of Central Java. The observed area is the area of natural raw materials handicraft center. Specifically, for this scientific article, Magelang - Central Java region becomes the focused area of this research. The MSMEs that are specifically observed are those that use natural raw materials as processed handicraft products.

The methodology used is qualitative descriptive, involving 30 respondents in Magelang. All respondents were willing to be met in the field, and they provided information through questionnaires. The interview process directly dug up information about the actual conditions of the MSMEs players. There were 18 questions covering the profile of MSMEs, MSMEs businesses before the pandemic period, during the pandemic period and plans for MSMEs players to enter the New Normal period.

The qualitative descriptive results were processed into data tables and descriptive records of each partner met in the field were made. The descriptive results from partners enclosed documentation as an integrated part of the research method being done.

Because the focus of this scientific article is on digital marketing, the discussion presented is very specific; it is about digital marketing that utilizes information technology.

\section{FINDINGS AND DISCUSSION}

MSMEs profiles for natural raw materials presented in Table 1 are obtained from the visited field and interviews. Most of the respondents are male who has the skills, talents and creativity in managing natural raw materials into high-value art craft products. However, only about 56 percent of the total respondents have the name MSMEs as an identity label, whereas the rest do not have an identity. In fact, if traced further, most of the MSMEs already have a fairly established business age. With a fairly well-established business age, MSMEs certainly have a sufficient number of workers. 
Journal of Social Entrepreneurship Theory and Practice (JSETP), Vol. 1 (1), 68-83

How Far the Digital Marketing Innovation done by Natural Raw Material MSMEs during the Pandemic?

Case of Magelang Region, Central Java Region, Indonesia

Hironimus Leong, Berta Bekti Retnawati, B. Irmawati

Table 1. Respondent Profile

\begin{tabular}{|c|c|}
\hline GENDER & TOTAL \\
\hline Male & 25 \\
\hline Female & 5 \\
\hline
\end{tabular}

\begin{tabular}{|c|c|}
\hline NAME & TOTAL \\
\hline Having & 17 \\
\hline Not Having & 13 \\
\hline
\end{tabular}

\begin{tabular}{|c|c|}
\hline BUSINESS AGE & TOTAL \\
\hline$>$ 10 Years & 19 \\
\hline 1 Up To 5 Year & 3 \\
\hline 6 Up To 10 Years & 8 \\
\hline
\end{tabular}

Source: The Processed Primary Data, Year 2020

MSMEs have around 1 up to 5 employees, and some of them have their own families to be the employees. Table 2 describes the numbers of employees and the types of business. MSMEs in Magelang that become respondents in this research are categorized into 5 kinds of natural raw materials business. They are handicrafts of bamboo, batik, wood, shells, and horns. Bamboo and wood handicrafts dominate natural raw materials MSMEs in Magelang region because there are abundant availability of natural raw materials in this area, and they become iconic handicrafts products from Magelang.

Table 2 Number of Employees and Type of Business

\begin{tabular}{|c|c|}
\hline NUMBER OF EMPLOYEES & TOTAL \\
\hline > 10 People & 1 \\
\hline 1-5 People & 10 \\
\hline 6-10 People & 2 \\
\hline Their Own Family & 7 \\
\hline
\end{tabular}

\begin{tabular}{|l|c|}
\hline \multicolumn{1}{|c|}{ TYPE OF BUSINESS } & TOTAL \\
\hline Bamboo Crafts & 15 \\
\hline Batik Crafts & 1 \\
\hline Wood Crafts & 11 \\
\hline Shell Crafts & 1 \\
\hline Horn Crafts & 2 \\
\hline
\end{tabular}

Source: The Processed Primary Data, Year 2020

Before the pandemic period, natural handicraft MSMEs could produce hundreds of products per month (Figure 1). Bamboo products such as pens, bracelets, key chains, as well as traditional products such as tamper, kaloe and ireg, could be distributed to local markets. Wooden products such as scoops, cutlery, carved wall clocks, tissue boxes and nameplates, and also children toys such

72 
as wooden trucks and horse-drawn carriages also got quite a lot of markets around the tourist areas in Magelang.

The interesting one is the production of natural handicrafts made of shells such as plasmet and shell key chains. The production reached the highest number, 3000 productions per month, although Magelang region is not a coastal area that produces natural shellfish products. All-natural materials are imported from other regions and then processed into art products and distributed abroad.

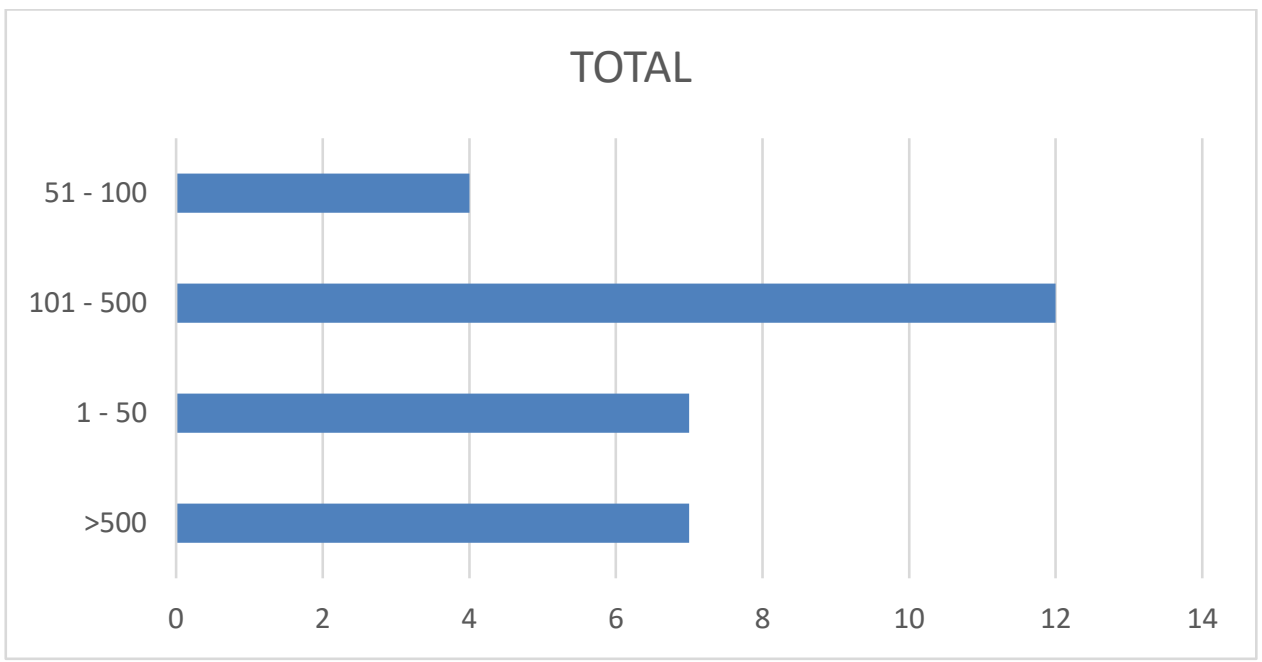

Figure 1. Total Production Per Month Before the Pandemic Period Source: the processed primary data, Year 2020

The targeted market for natural material production is mostly on a national scale (70\%), such as big cities on the island of Java-like Semarang, Yogyakarta, Jakarta and Bandung. The marketing area also does not leave the local market (20\%) around the Central Java region. Meanwhile, $10 \%$ of natural raw material MSMEs have marketed their products to foreign countries such as America, Spain and Argentina. Figure 2 is a distribution diagram of the MSMEs market for natural raw materials based on the marketing area.

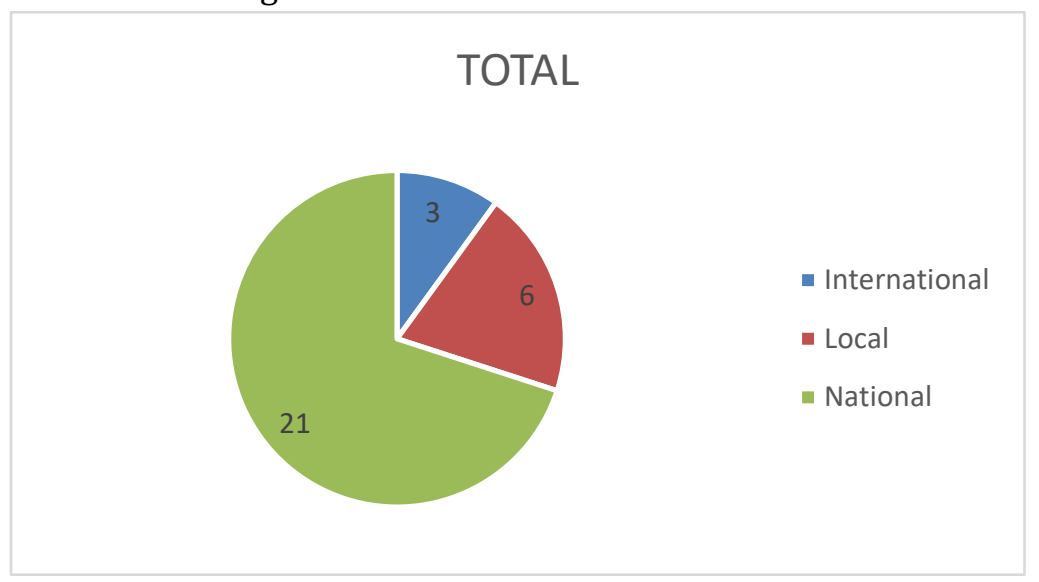

Figure 2. MSME Marketing Areas

Source: the processed primary data, Year2020 
During the pandemic period, $60 \%$ of MSMEs businesses have experienced a decline (Figure 3); $36 \%$ of the MSMEs that are not affected are those that are in the process of completing the orders which were made before the pandemic. Only 1 MSME has experienced an increase in marketing. Interestingly, from interviews with some MSME players who are not significantly affected, the use of social media for marketing is the key. Business people who use information technology for marketing can expand market access both locally and abroad.

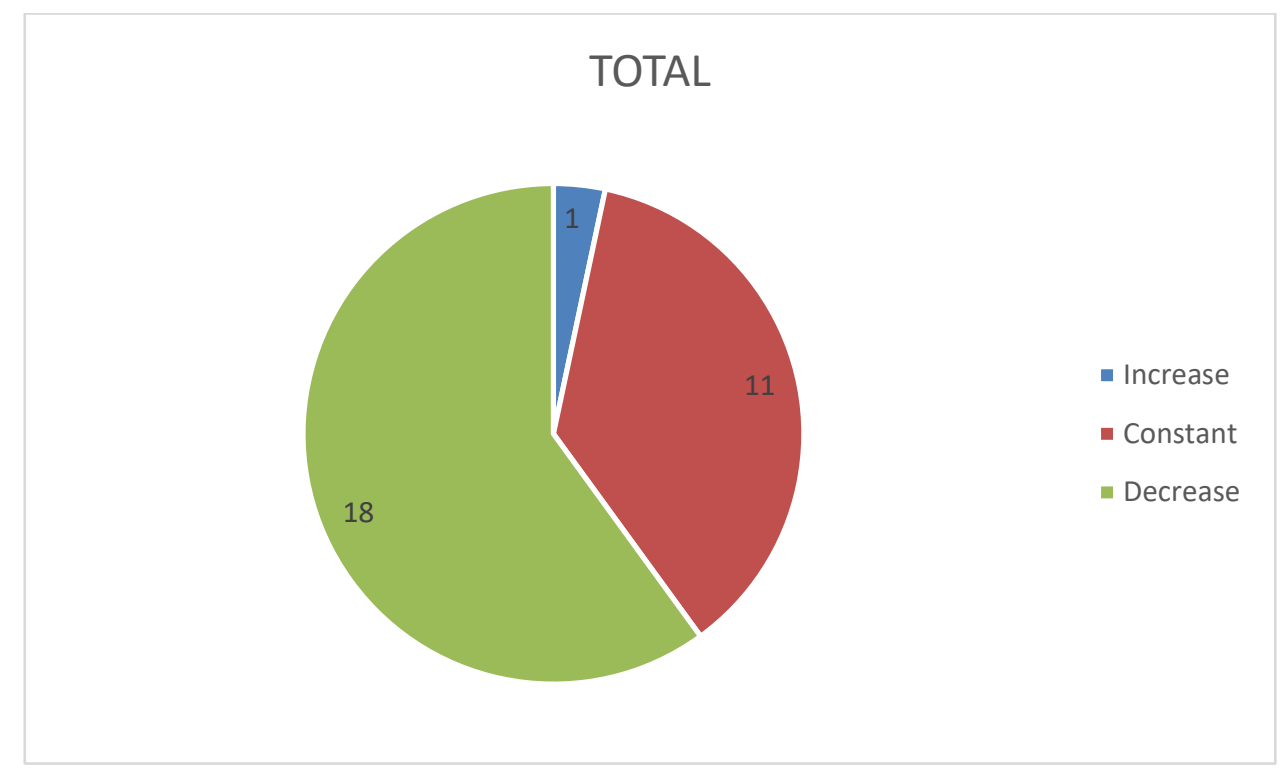

Figure 3. Impact on MSME Enterprises

Source: The Processed Primary Data, Year 2020

Natural raw material MSMEs that utilize information technology are able to adapt to markets that quickly immigrate to digital. Although marketing is still done traditionally by some MSMEs players, various digital traces of several MSME natural raw materials can be found and survive to this day. Here are some profiles of natural raw material MSMEs that take advantage of digital opportunities in product marketing.

\section{OMAH PRING}

MSME that is located in Kebon Wage village, Borobudur - Magelang. This MSME is managed by Heri Sutrisno. At the beginning of the business, Omah Pring produced chopped bamboo as the base material for making bracelets. In 1 month, 1000 bracelets were produced from 3 workers who helped the production process. Creative hands were needed in the process of producing products that had an aesthetic taste. Through PT. Asia Decor, chopped bamboo products could be exported to the United States. 


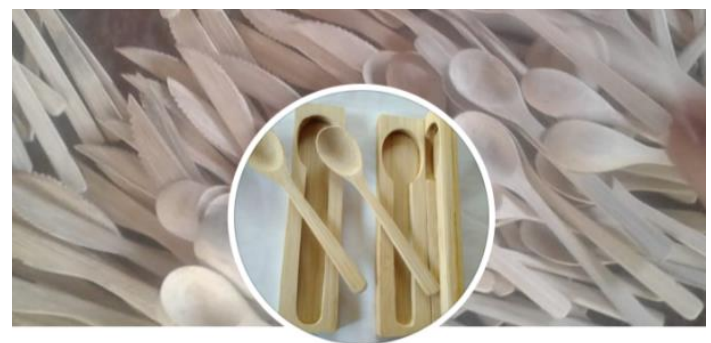

\section{Omah Pring Perkakas Rumah}

Figure 4. Omah Pring's Facebook Social Media

Source: Facebook, 2020

During the pandemic, Omah Pring has created an innovation by introducing new products with natural materials, namely bamboo. This began from a lot of requests through Omah Pring's social media on Facebook to make kitchen utensils from bamboo. The products produced during the pandemic are spoons, forks, knives and glasses.

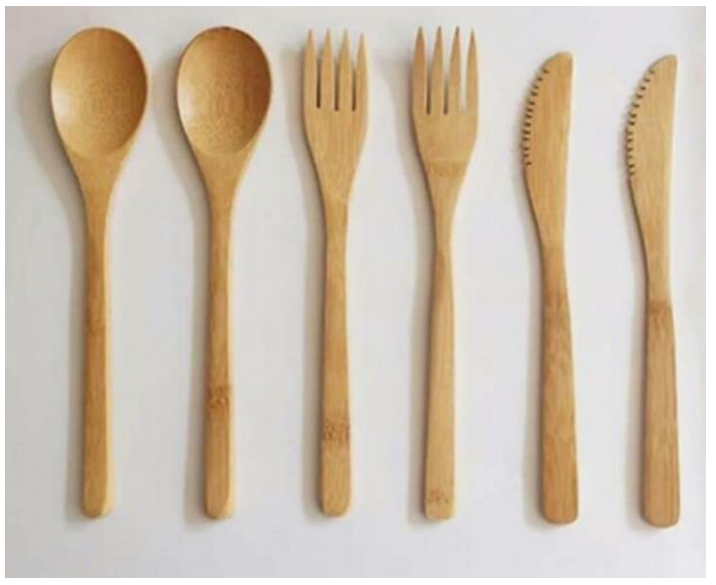

Figure 5. Omah Pring Kitchen Products

Source: The Research Team Collection, 2020

During the pandemic, the production is still running. Orders from the Bali region has reached hundreds of pieces per month to meet the needs of hotels and tourism on the island of the gods. The main challenge does not lie in marketing problems because the use of digital platforms really helps the products to be known to foreign countries. The main challenge is the availability of tools for production in large quantities because so far, all productions have been done manually by hand. 


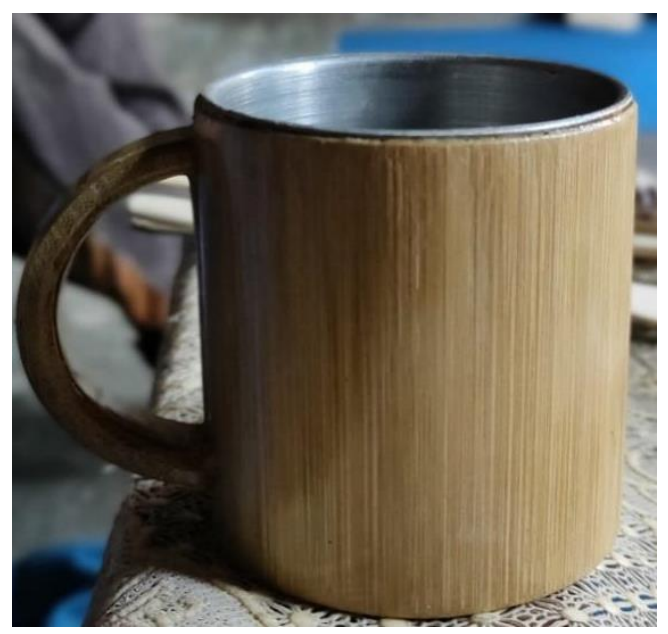

Figure 6. Omah Pring Bamboo Glass Products Source: The Research Team Collection, 2020

Omah Pring's business and marketing innovations produce new products and display various product samples on digital social media platforms. Besides using Facebook as a promotion medium, Omah Pring uses the WhatsApp platform to market products. The number of orders continues to increase because of the use of the digital platform. Moreover, the presence of resellers has given the most contribution to online marketing. Resellers from West Java and Jakarta have become strategic market partners for Omah Pring in developing its business during the adaptation period of new habits.

\section{SABILA CRAFT}

Prajoko's MSME that is on Jalan Raya Magelang City. This MSME business produces laminated natural shellfish handicrafts, such as key chains, plasmet and shell baskets. This MSME has been run for 18 years, and it has employed 50 people.

The raw material for MSMEs is shellfish that depends on the season, meaning that the amount of the raw material is abundant at certain times, while at other times, the amount of the raw material is very limited. Because Magelang is not a coastal area, so the raw material is imported from other areas, especially from the north coast of Java.

\section{SabilaCraft.Creative}

\section{Semua Foto}
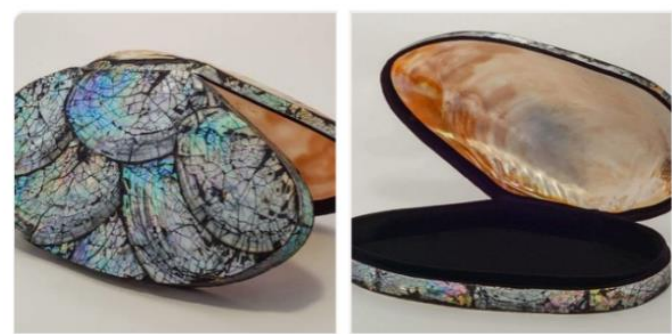
Journal of Social Entrepreneurship Theory and Practice (JSETP), Vol. 1 (1), 68-83

How Far the Digital Marketing Innovation done by Natural Raw Material MSMEs during the Pandemic? Case of Magelang Region, Central Java Region, Indonesia Hironimus Leong, Berta Bekti Retnawati, B. Irmawati

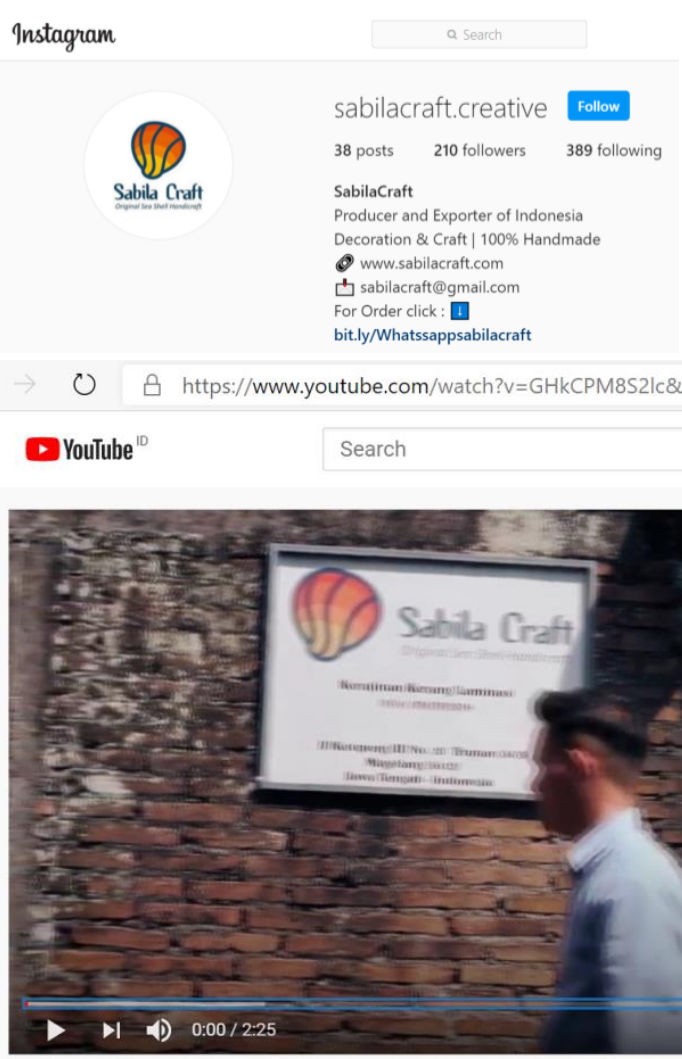

Figure 7. Social Media Facebook, Instagram and Youtube Sabila Craft Source: Facebook - Instagram and Youtube, 2020

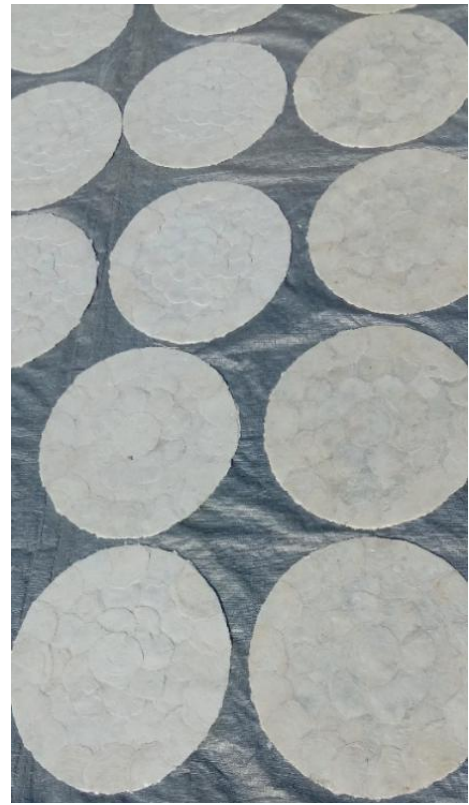

Figure 8. Shells Raw Material

Source: The Research Team Collection, 2020 
During the pandemic period, the sending process becomes late because of the health protocol that must be applied. The social limit that has been applied for some months has caused Sabila Craft MSME to stop production. This has continued until the period of new habit adaptation. The number of workers has been reduced up to 10 people.
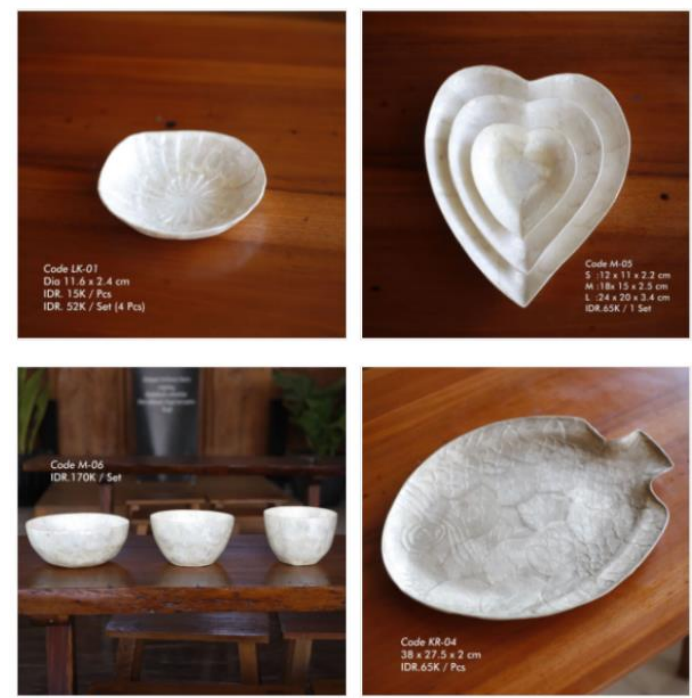

Figure 9. Sabila Shell Craft Products Source: Facebook, 2020

The strategy done in creating new product creations is adaptive. New products are created when there are demands from customers. This is where the role of social media is needed to advertise products information to the market. The results of product creations are made in a product catalogue with an attractive digital format, and they are offered to buyers. Products offered digitally can easily be accessed through the official website page http://sabilacraft.com/

From the aspect of information technology, informative web development can help broaden product marketing. Technology helps centralize MSME information in an integrated way. Through the web, Sabila Craft has succeeded in introducing its profile, the products it produces, the identity of the UMKM that can be contacted through various communication links, order methods, and even the payment confirmation process. 

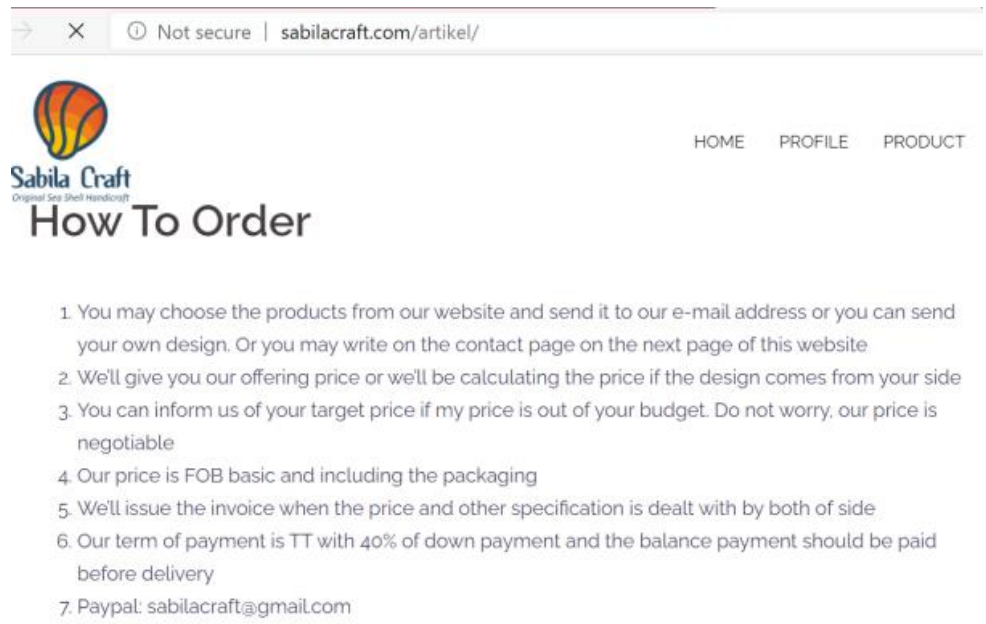

Figure 10. Integrated Web Sabila Craft

Source: sabilacraft.com, 2020

The biggest challenge for UMKN Sabila Craft is not the raw materials but the number of skilled workers for this craft that is very limited. A worker with a talent for creativity and innovation is also needed to produce products that can be accepted by foreign markets.

\section{ARIF HORN COLLECTION}

MSME that was founded by Fatkhul Arif, one of the horn craftsmen in Puchong Village, Sepang District, Magelang Regency. The people of Pucang Village have been crafting horns since the days of Pangeran Diponegoro hundreds of years ago. In the 1980s, horn handicraft products were exported to foreign countries, such as France and the Netherlands.

Arif never studied formally to become a horn craftsman. This expertise is obtained from the results of autodidact learning from parents and the people around him. In addition to hereditary skills, Arif has studied and deepened his expertise through books and online media. From the results of this study, besides horns, there are also various kinds of handicrafts made of bone material. The handicrafts are then marketed by selling them to wholesalers, then they enter the export market and participate in various exhibitions in Indonesia and abroad, both offline and online or virtual.

Processing the natural horns into crafts does not only require skill and a touch of art, but it also requires perseverance because the processing time required is quite long. The process begins with drying the horns under the sun; then, the burning process is carried out to make them more flexible and easier to shape. The final stage is pressed and formed into sheets that are ready to be molded according to the ordered- model. To meet the need for raw materials, the natural horns are brought from Kalimantan and Sumatra. However, day by day, raw materials are getting rare. 
Journal of Social Entrepreneurship Theory and Practice (JSETP), Vol. 1 (1), 68-83

How Far the Digital Marketing Innovation done by Natural Raw Material MSMEs during the Pandemic? Case of Magelang Region, Central Java Region, Indonesia Hironimus Leong, Berta Bekti Retnawati, B. Irmawati
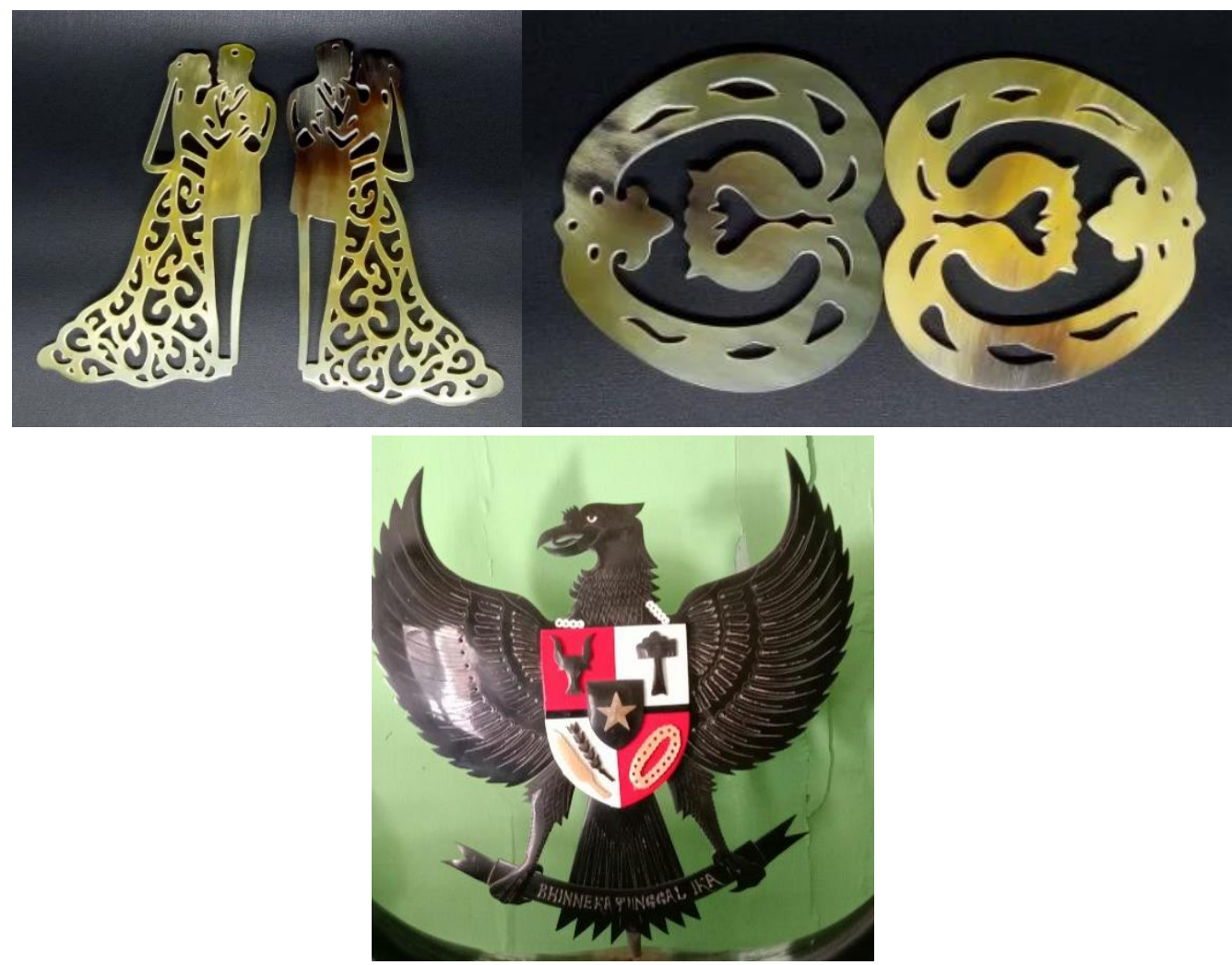

Figure 11. Souvenir made of natural horn Source: The Research Team Collection, 2020

Arif has 3 workers who work on products according to the number of orders. There is no fixed number of productions every month because it depends on the order process from the buyer. During the pandemic, the highest orders have been cigarettes or cigars pipes that are shipped to the regions of Sumatra, Jakarta, Kalimantan, Bali and Yogyakarta.

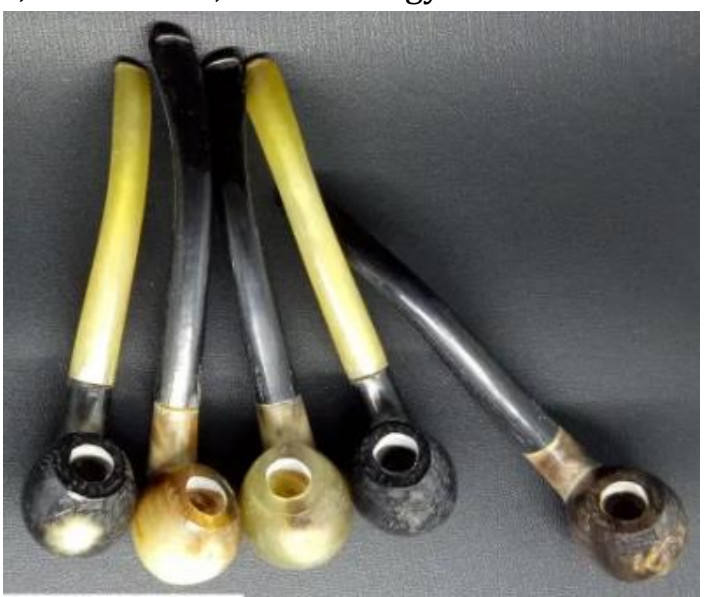

Figure 13. Cigarette / Cigar Pipe made of natural horn

Source: The Research Team Collection, 2020 
Marketing is also done online via a WordPress-based web. The display is quite simple; there are not too many elements, focusing only on displaying the gallery of products made from natural horns and bones completely. According to Arif, from a simple web that has been developed since July 2018, it has provided information on craft products to buyers.

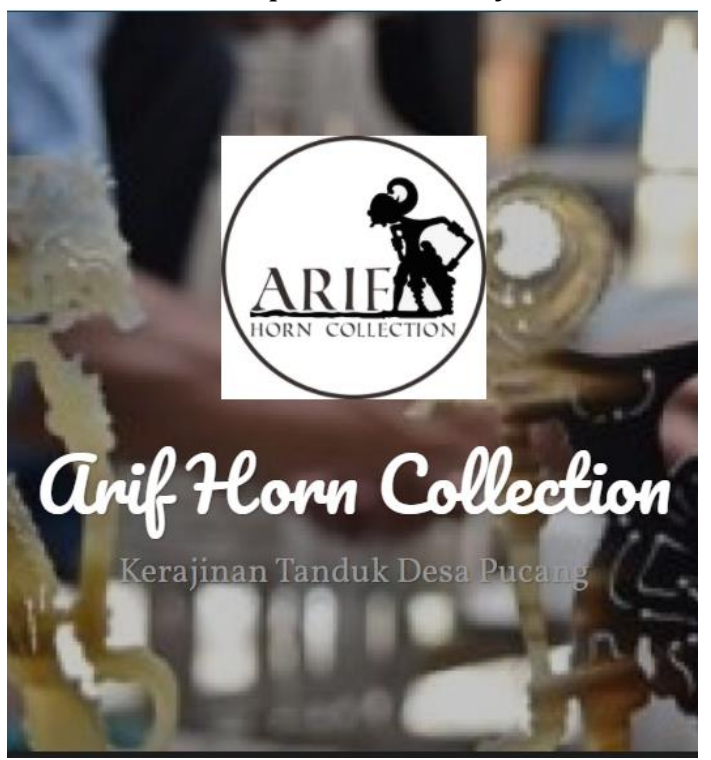

Figure 14. Screenshot of Arif Horn Collection Web

Source: arifhorncollection.wordpress.com, 2020

From the 3 profiles of MSMEs natural materials handicrafts that have innovation in marketing using digital platforms, it can be seen that there are some important aspects of digital marketing excellence. First, digital marketing provides a map for buyers in finding the results of MSMEs products that are made of natural materials. Through social media such as Facebook, Instagram or YouTube, consumers can easily find the product they are looking for through the official website, or even through status from chat media such as Whatsapp or from social media related to help the product's market.

Second, products marketed through digital platforms can provide complete information about the products that buyers are looking for, contacts that can be contacted to ask for information about products and can even conduct electronic transactions through digital platforms. Complete information is not only about the contacts who can be contacted but also about how to process orders, delivery, and payment.

Third, digital marketing can help MSMEs develop competition with other products. Buyers can make a comparison of product quality and price before deciding to make a purchase. A very broad reach is the key for MSME players to introduce their products and to open opportunities for buyers to ask questions and consult and also offer through devices without having to be physically present. Online marketing still provides equal quality for MSMEs to compete with other business players.

Fourth, buyers can share information with others regarding MSME products with natural raw materials to others. Digital marketing is able to help the process of distributing information to a 
wider market. The process for sharing information on new products and models can also take place quickly. The sales product evaluation process also gets feedback quickly from the buyers.

Fifth, digital marketing can indirectly help establish product branding. Through a digital platform, natural raw materials MSMEs can leave messages (stories) that are relevant to the products produced. With digital marketing, MSME players will look more professional in doing business when compared to traditional conventional businesses that seem to be left behind.

\section{CONCLUSION}

The majority of MSME players that use natural raw materials for the products in this study are male, where most of the MSMEs already have their own business names and have been running their business for more than 5 years. Natural handicrafts that are mostly found in the Magelang area are crafts made of wood and bamboo. Generally, they have a number of workers on a microscale, about 1-5 people, including the family members. Before the pandemic, the average production of handicrafts was in the range of 100 to 500 pieces per month. Production results were distributed nationally in several big cities and regions in Indonesia; even a small proportion of MSMEs managed to sell their products to foreign countries.

During the pandemic, MSME players have experienced a decline in production. More than 50 percent of the MSMEs in this study have experienced a reduction in production. A small number of people have transformed their marketing methods from traditional conventional methods to digital-based marketing so that they can survive during the pandemic period. Social media and websites are used by MSME players to introduce their products via the internet. At the same time, MSME players do more innovations by creating other new products with high artistic value. It is proven that by doing digital marketing, MSMEs can keep hopes of surviving in difficult times.

The pandemic has taught MSMEs one important thing, that is the need for digital transformation that cannot be avoided. Only by entering the digital ecosystem, MSMEs can keep hopes to survive, to increase the revenue, to maintain the employees to keep on working, and to open the markets access as wide as possible and also to create new job vacancies and help the economic recovery.

\section{FURTHER RESEARCH}

This research is limited to the number of MSMEs respondents that create products from natural materials in Magelang region - Central Java. The results of the research can provide a complete and more comprehensive picture if it is also carried out in other areas in Central Java by involving more respondents. Digital marketing carried out by MSME players can be seen more broadly, not only in using digital media for marketing but also in using e-commerce technology for transactions that can be explored further.

\section{REFERENCES}

Caddell, B. (2020, 11 23). Digital Strategy 101 is an overview of the current state of digital strategy. Retrieved from Digital 101: http://www.slideshare.net/bud_caddell/digitalstrategy-101-24081694

Data UMKM. (2020, 11 27). Retrieved from Kementerian Koperasi dan Usaha Kecil dan Menengah: http://www.depkop.go.id/data-umkm 
Kotler, P., \& Levy, S. (1969). Broadening the Concept of Marketing. Journal of Marketing (Vol. 33, No.1), 15.

Kotler, P., Kartajaya, H., \& Setiawan, I. (2017). MARKETING 4.0 Moving from Traditional to Digital. New Jersey: John Wiley \& Sons, Inc.

Retnawati, B., \& Irmawati, B. (2018). Peningkatan Kinerja Pemasaran UMKM Produk Kerajinan Berbahan Baku Alam di Jawa Tengah Melalui Nurturing Iconic Product Innovation. Semarang: Soegijapranata Cactholic University.

Ryan, D. (2014). Understanding Digital Marketing. New Delhi: Kogan Page.

Silvatika, B. A. (2020). Technosociopreneur, New Model UMKM di Era New Normal. Prosiding Seminar Stiami , 32.

Soetjipto, N. (2020). Ketahanan UMKM Jawa Timur Melintasi Pandemi Covid 19. Yogyakarta: Penerbit K-Media. 